\title{
APPLYING IHL TARGETING RULES TO PRACTICAL SITUATIONS: PROPORTIONALITY AND MILITARY OBJECTIVES
}

\section{William J. Fenrick*}

The IHL targeting rules are framed in relatively abstract terms and there is, unfortunately, no general agreement concerning precisely which objects constitute military objectives and concerning the relative values to be assigned to civilian losses and military advantages when computing the proportionality equation. The author encourages the development of a dialogue between all informed and interested parties, based in large part on case studies, to clarify the concepts.

Les règles du DIH sur le choix des objectifs sont rédigées en termes passablement abstraits et il n'y a malheureusement pas d'accord général au sujet de précisément quels objets constituent des objectifs militaires ainsi qu'au sujet des valeurs relatives à accorder aux pertes civiles et aux avantages militaires pour établir l'équation de proportionnalité. L'auteur préconise le développement d'un dialogue entre toutes les parties renseignées et intéressées, basé en grande partie sur des études de cas, dans le but de clarifier les concepts.

\section{INTRODUCTION}

The primary purpose of International Humanitarian Law [IHL] is to reduce net human suffering in armed conflict. Such human suffering is caused in a variety of ways. Persons in areas under the control of a party to a conflict may be deliberately mistreated. Resources may be denied to persons inside or outside areas under the control of a party to a conflict. A significant proportion of human suffering, including death or injury to civilians and damage to civilian objects, occurs during combat when objects or persons are targeted and attacked.

The principle of distinction underlies all IHL targeting rules and this principle obligates those involved in military operations to distinguish between legitimate targets and unlawful targets. IHL targeting rules can be summarized as follows: first, military operations must be directed against legitimate targets and these include military objectives (things), combatants and civilians taking a direct part in hostilities; second, attacks directed against unlawful targets, that is, civilians and civilian objects, are prohibited; third, indiscriminate attacks, those which do not distinguish between lawful and unlawful targets, are prohibited; and last, attacks which are directed against lawful targets but which it is anticipated will cause excessive or disproportionate harm to civilians or damage to civilian ob-

* Dalhousie University Law School. The author was a military lawyer in the Canadian Forces (1974-94) and a Senior Legal Adviser in the Office of the Prosecutor [OTP] of the International Criminal Tribunal for the former Yugoslavia [ICTY] (1994-2004). The views expressed in this article are personal and do not necessarily reflect the views of any institution with which the author has been or is affiliated. 
jects are prohibited. Application of the targeting rules to concrete situations is at times contested for one of two reasons: (i) because the concepts embraced by the rules are inadequately defined, proportionality is the prime example; or (ii) because there has been inadequate discussion of how the defined concept should be applied to specific instances. There is an agreed definition of military objective but considerable disagreement concerning its application. Quite clearly, in many situations the existing articulation of the rules is adequate. No one would suggest that an attack on an ammunition dump is not an attack on a legitimate military objective or that an attack on a school occupied exclusively by children and their teachers is an attack on a legitimate military objective. Similarly, it is unlikely many would suggest that an attack on an armoured formation which resulted in a single civilian casualty and the destruction of several tanks was disproportionate, although there are some who do argue one civilian casualty is disproportionate.

Clarification and amplification of IHL targeting rules, with a resultant reduction of net human suffering, is also hampered by the fact that such discussion as does take place occurs in two different forums and the discussants in each forum do not communicate adequately with the discussants in the other. On the one hand, legal advisers to the armed forces of nations which take their IHL obligations seriously, such as Canada, the USA and the UK, do advise on targeting issues on a regular basis and, one presumes, have developed a body of knowledge and opinions on targeting issues which has a substantial impact on targeting decisions. These "insiders" have an understanding of military operational factors as well as law which entitles their opinions to particular weight. Necessarily or unnecessarily, however, their opinions are issued behind closed doors and could conceivably result in the development of a form of hot house law which would not survive if exposed to outside criticism. In recent years, outside observers with varying degrees of familiarity with IHL targeting rules and with military operational factors have also begun a public discussion concerning targeting issues. A few of these outside observers have a high degree of expertise in IHL and in military operational factors which are relevant to targeting. Some of the reports by Human Rights Watch and by Amnesty International indicate a high degree of familiarity with such fields. ${ }^{1}$ Other outside observers, however, demonstrate a higher degree of familiarity with rhetoric or with polemics than with anything related to targeting. ${ }^{2}$ Regrettably, outsiders and insiders do not talk to each other or, at least, do not talk to each other enough. ${ }^{3}$ There is a substantial risk that

1 Two examples of reports prepared by knowledgeable outsiders are: Amnesty International, 'Collateral Damage' or Unlawful Killings? Violations of the Laws of War by NATO During Operation Allied Force (London: Amnesty International, 2000); and Human Rights Watch, "Troops in Contact:" Airstrikes and Civilian Deaths in Afghanistan (New York: Human Rights Watch, 2008).

2 As a lawyer in the ICTY OTP during and after the NATO bombing campaign over Yugoslavia in 1999, the author was the recipient of many briefs criticizing NATO bombing prepared by transient one person organizations with a debatable level of relevant expertise.

3 One exception is the Project on the Means of Intervention conducted by the Carr Centre for Human Rights Policy at Harvard University in 2001-3. This project endeavoured to bring together military and non-military experts in a variety of fields, including military operations, 
two bodies of law will develop addressing the same issues: a "confidential" body of law developed and circulated among themselves by insiders who may have some special interests such as client protection; and a body of law developed by outsiders who may be unduly tainted by both idealism and ignorance. Such a development would be terribly unfortunate for the positive development of IHL and for the accomplishment of its main purpose, the reduction of net human suffering in armed conflict.

There is a need for informed and fair minded insiders and outsiders to meet online or in person or through academic periodicals to discuss, and hopefully to agree on, the clarification and amplification of the IHL targeting rules in a public context. It may be that involvement in an educational process in military operational factors and in IHL should be a prerequisite for involvement in the discussion process.

Litigation is not a usable substitute for such a discussion process. The concept of negligence in tort law, abstract in origin, may have been elaborated upon quite adequately by thousands of court cases. Such a process will not occur in IHL. ${ }^{4}$ Cases involving the application of IHL targeting rules have been litigated but these will always be few because of lack of opportunity, extreme expense, and the simple fact that prosecutors, if given a choice, will prefer to prosecute a case in which the crime base is certain in lieu of one in which it is debatable that an offence occurred in the first place. The last point accounts in part for the reluctance of the ICTY Prosecutor to commence an investigation into the possible criminal culpability of NATO leaders for directing the bombing of the RTL TV/Radio Station in downtown Belgrade during the Kosovo related bombing campaign in 1999.5

The International Committee of the Red Cross [ICRC] has now completed a discussion process attempting to clarify the meaning of "civilians taking a direct part in hostilities." ${ }^{\prime \prime} \mathrm{A}$ similar process is necessary to clarify and amplify the meanings and practical applications of "military objective" and of "proportionality" if discussion is to evolve beyond what the writer, a former naval officer, remembers being described as a wardroom argument: a positive assertion followed by a flat denial followed by personal abuse. Specific and elaborate case studies based on actual incidents from recent conflicts or hypothetical examples would help to bring debate down from the general to the particular level. There is no need for these case studies to address matters which raise current security issues. A discussion of incidents from the NATO Kosovo-related bombing campaign of 1999, for example, should not raise security issues today.

law, just war theory, philosophy, political science, and collateral damage analysis in order to attempt to develop common ground for reducing civilian casualties in modern conflicts. The author was fortunate to be involved in the process.

4 William J. Fenrick, “The Prosecution of Unlawful Attack Cases Before the ICTY” (2004) 7 Y. B. Int'l.Human L. 153.

5 "Final Report to the Prosecutor by the Committee Established to Review the NATO Bombing Campaign Against the Federal Republic of Yugoslavia” (2000) 39 I.L.M. 1257 at 1277-80 [NATO Bombing Report].

6 Dr. Nils Melzer "Interpretive Guidance on the Notion of Direct Participation in Hostilities Under International Humanitarian Law” (2008) 90 Int'l Rev. Red Cross 991. 
The remainder of this article attempts to facilitate the development of a common approach to the application of IHL targeting rules by identifying issues related to military objectives and proportionality which appear to require elaboration or clarification and by making some observations concerning the way ahead.

\section{MILITARY OBJECTIVES}

Military objectives are things which may be attacked lawfully. One of the early attempts to define military objectives is contained in Article 24 of the draft 1923 Hague Air Warfare Rules. In Article 24(1), a military objective is defined as: "an objective where the total or partial destruction would constitute an obvious military advantage for the belligerent" and the following paragraph itemizes military objectives as: "military forces, military works, military establishments or depots, manufacturing plants constituting important and well-known centres for the production of arms, ammunition or characterized military supplies, lines of communication or of transport which are used for military purposes." These rules were not adopted by states and a much broader approach to the concept of military objective was followed in World War II.

Article 52(2) of Additional Protocol I [AP I] provides the definition of military objectives which is most widely accepted at present:

In so far as objects are concerned, military objectives are limited to those objects which by their nature, location, purpose or use make an effective contribution to military action and whose total or partial destruction, capture or neutralization, in the circumstances ruling at the time, offers a definite military advantage. ${ }^{8}$

Paragraph 3 of the same Article indicates that in case of doubt over whether an object, which is normally dedicated to civilian purposes, is being used to make an effective contribution to military action, it shall be presumed not to be so used. The definition has two elements: (a) that the nature, location, purpose or use of the object must make an effective contribution to military action, and (b) that the total or partial destruction, capture or neutralization of the object must

7 “(1923) Hague Rules Concerning The Control of Wireless Telegraphy in Time of War and Air Warfare" in Dietrich Schindler \& Jiri Toman, eds., The Laws of Armed Conflict $4^{\text {th }}$ ed (Lieden: Martinus Nijhoff, 2004) 315 at 319.

8 “(1977) Protocol Additional to the Geneva Conventions of 12 August 1949, and Relating to the Protection of Victims of International Armed Conflicts (Protocol I)", ibid. 711 at 737. Commentary concerning this definition is contained in Yves Sandoz et al, eds., Commentary on the Additional Protocols of 8 Jun 1977 to the Geneva Conventions of 12 August 1949 (The Hague: ICRC/Martinus Nijhoff, 1987) 635 [ICRC Commentary]; and Michael Bothe et al, New Rules for Victims of Armed Conflict (The Hague: Martinus Nijhoff, 1982) 323. See also Anthony P.V. Rogers, Law on the Battlefield, 2nd ed. (Manchester: Juris, 2004) 58-85; and Yoram Dinstein, The Conduct of Hostilities Under the Law of International Armed Conflict (Cambridge: Cambridge University Press, 2004) 82. 
offer a definite military advantage in the circumstances ruling at the time. There is, unfortunately, no general agreement concerning the values to be assigned to specific military advantages. A number of countries which have ratified AP I, including Canada, have submitted declarations on ratification indicating a specific area may constitute a military objective. ${ }^{9}$

The ICRC, states which have ratified $A P I$, and most other states, including the USA, would probably regard the $A P I$ definition of military objective as a reasonably accurate definition applicable as a matter of customary law to all conflicts. Indeed, this is the view expressed in the ICRC Customary International Humanitarian Law Study [CIL Study]. ${ }^{10}$

The definition is difficult to apply to dual use objects which have some civilian uses and some actual or potential military uses (such as communications systems, transportation systems, petro-chemical complexes, or manufacturing plants of some types). The application of the definition to particular objects may produce different results depending on the scope and objectives of a conflict. Further, the scope and objectives of a conflict may change over time.

It should be noted that the USA appears to have adopted a substantially broader definition of military objective for its Military Commission Instructions:

\begin{abstract}
"Military objectives" are those potential targets during an armed conflict which by their nature, location, purpose or use, effectively contribute to the opposing force's war fighting or war-sustaining capability and whose total or partial destruction, capture or neutralization would constitute a military advantage to the attacker under the circumstances at the time of the attack $^{11}$
\end{abstract}

At first glance, the reference to "war-sustaining capability" would appear to extend beyond the API definition. One must also observe that W. Hays Parks, who has been the leading legal authority on law of war issues in the US Defense Department for the last thirty years, is of the view that the AP I definition of military objective is unduly restrictive. ${ }^{12}$

It is suggested that adoption of the $A P I$ definition of military objective should have inaugurated a debate concerning how it should be applied in different contexts. Unfortunately, this debate has not occurred. At the very least, widely differing views have been expressed concerning issues such as:

(1) Should more or fewer things be regarded as military objectives by the intervening side during a humanitar-

9 The relevant Canadian declaration is in Schindler \& Toman, supra note 7, at 798.

10 Jean-Marie Henckaerts \& Louise Doswald-Beck, Customary International Humanitarian Law (Cambridge: ICRC/Cambridge University Press, 2005), at Vol I Rule 8, Rules, 29-32 and Vol. 2 at $181-232$.

11 USDOD, Military Commission Instruction No. 2, Art. 5D (30 Apr 2003).

12 William Hays Parks, "Air War and the Law of War" (1990) 32:1 A.F.L. Rev. at 135. 
ian intervention or by the "good" side during an armed conflict? ${ }^{13}$

(2) Should civilian morale be regarded as a military objective? ${ }^{\text {14 }}$

(3) Should the political leadership be regarded as a military objective? ${ }^{35}$

(4) How does one reconcile the approach adopted by some countries of "effects based targeting," which focuses on attacks directed against objects which will have an ultimate beneficial military effect with the requirement to direct attacks against military objectives?

One approach which might be worth exploring further is that adopted in the, admittedly unofficial, San Remo Manual on International Law Applicable to Armed Conflicts at Sea. The drafters of that document both adopted the AP I military objective definition for sea warfare and then went on to provide agreed illustrative lists of vessels which would be subject to attack in certain circumstances. ${ }^{16}$

\section{PROPORTIONALITY}

"Proportionality" refers to the comparative ratio between things. Proportionality is relevant to IHL rules concerning targeting as, when an attack is directed against a material military objective, combatants or civilians taking a direct part in hostilities, the anticipated collateral or incidental loss of life, injury to civilians, and damage to civilian objects must not be excessive or disproportionate to the anticipated military advantage derived from the attack.

The word "proportionality" may be used in various other contexts, such as the disproportionate use of force when one side has or uses greater military resources

13 Charles J. Dunlap, “The End of Innocence: Rethinking Non-Combatancy in the Post-Kosovo Era" (2000) Summer Strategic Review 4, has suggested that the "good" side should be permitted to attack a broader range of material objectives. Unfortunately, views may differ concerning which is the good side.

14 For a vigorous statement of the view that enemy civilian morale has traditionally been regarded as a legitimate military objective and that the AP I definition of military objective should be interpreted as legitimizing attacks on morale targets, see Jeanne M. Meyer, "Tearing Down the Façade: A Critical Look at the Current Law on Targeting the Will of the Enemy and Air Force Doctrine" (2001) 51 A.F.L.Rev. 143.

15 See extended discussion of practical aspects of attempting to attack Saddam Hussein in "Off Target: The Conduct of the War and Civilian Casualties in Iraq" (New York: Human Rights Watch, 2004) 21-40.

16 Louise Doswald-Beck, San Remo Manual on International Law Applicable to Armed Conflicts at Sea (Cambridge: International Institute of Humanitarian Law/Cambridge University Press, 1995) 15-25. Various target lists, theoretical and applied, are referred to and quoted in the NATO Bombing Report, supra note 5 at 1266-70. 
in a particular situation. While the use of the expression may be factually accurate in such a context, it is also legally irrelevant in a targeting context. There is nothing unlawful about using more or better equipment or troops than an opponent uses; armed conflict is not a sporting contest, and while the rules must be obeyed, there is no legal requirement to have a level playing field. Military forces strive to have a technological advantage, and an attacking force usually strives to have at least a three to one margin of superiority in equipment and troops.

Prior to the conclusion of $A P I$, there was no binding treaty provision applicable in armed conflict which explicitly required the application of the rule of proportionality in combat. Moreover, there was some debate concerning whether or not the rule of proportionality was a customary rule of law applicable in armed conflicts. This debate is pointless because whether or not proportionality is formally embodied in customary law, it is a logically necessary part of any decision making process which attempts to reconcile humanitarian imperatives and military requirements during armed conflict. The reconciliation requirement is widely recognized.

The principle of proportionality is implicitly contained in Article 51 of AP I, which prohibits indiscriminate attacks and goes on to specify in Article 51(5) (b) that certain types of attack are indiscriminate, including when: "an attack may be expected to cause incidental loss of civilian life, injury to civilians, damage to civilian objects, or a combination thereof, which would be excessive in relation to the concrete and direct military advantage anticipated." The expression "excessive," considered in the AP I context, is synonymous with disproportionate. ${ }^{17}$ The proportionality equation compares anticipated military advantages with anticipated civilian losses, not end result advantages with actual civilian losses. Article 8(2)(b)(iv) of the ICC Statute uses the expression "clearly excessive" in lieu of "excessive" but its legal impact is probably substantially similar. ${ }^{18} \mathrm{Al}-$ though $A P I$ applies exclusively to international armed conflicts and there is no equivalent provision in $A P I I$ which applies to non international armed conflicts, the authors of the ICRC CIL Study have concluded that a similar rule applies to all armed conflicts: "Rule 14. Launching an attack which may be expected to cause incidental loss of civilian life, injury to civilians, damage to civilian objects, or a combination thereof, which would be excessive in relation to the concrete

17 The drafting history of the provision is reviewed in William J. Fenrick, "The Rule of Proportionality and Protocol I in Conventional Warfare" (Fall 1982) 98 Mil. L. Rev. 91 at 98-112. For discussion of the provision see ICRC Commentary, supra note 8 at 623-6, and New Rules, supra note 8 at 309-11. The distinguished status of the ICRC Commentary notwithstanding, the author disagrees with para. 1980 (page 636) which states: "The idea has also been put forward that even if they are very high, civilian losses and damages may be justified if the military advantage at stake is of great importance. This idea is contrary to the fundamental rules of the Protocol, in particular it conflicts with Article 48 (Basic rule) and with paragraphs 1 and 2 of the present Article 51. The Protocol does not provide any justification for attacks which cause extensive civilian losses and damage. Incidental losses and damage should never be extensive." In the view of the author, proportionality is proportionality and the risk of substantial civilian losses may be faced if the anticipated military advantage is greater. The Protocol does not justify such losses. It accepts they may occur without being unlawful.

18 Otto Triffterer, ed., Commentary on the Rome Statute of the International Criminal Court (BadenBaden: Nomos Verlagsgesellschaft, 1999) at 197. 
and direct military advantage anticipated, is prohibited." 19

The main problem with the principle of proportionality is not whether or not it exists, but what it means and how it is to be applied. There must be an acceptable relation between the legitimate destructive effect and undesirable collateral effects. It is much easier to formulate the principle of proportionality in general terms than it is to apply it to a particular set of circumstances because the comparison is often between unlike quantities or values. How do you assess the value of innocent human lives as opposed to capturing or destroying a particular military objective? ${ }^{20}$

Some references were made to proportionality in the Galic Trial Decision before the ICTY. ${ }^{21}$ In Galic, the Trial Chamber was compelled to grapple with the issue in its discussion of one shelling incident, the shelling of the Dobrinje football tournament in Sarajevo on June 1, 1993. In that incident, about 200 spectators, including women and children, were watching a football game in the corner of a parking lot which was bounded on three sides by six-storey apartment blocks and on the fourth by a hill. Two shells exploded in the parking lot killing between twelve and sixteen persons and wounding between 80 and 140 persons. The players and many of the spectators were military personnel and, as such, legitimate targets. A slight majority of the killed and wounded were military personnel. Although assessing proportionality is not a simple exercise in number crunching, it would be difficult to conclude that, in the end result, disproportionate civilian casualties were caused unless one makes the arbitrary determination that civilian lives count for more than military lives. The majority of the Trial Chamber finessed an attempt to assess the proportionality of the result by focusing on the mens rea of the perpetrators and on the fact that civilian casualties were caused:

Although the number of soldiers present at the game was significant, an attack on a crowd of approximately 200 people, including numerous children, would clearly be expected to cause incidental loss of life and injury civilians excessive in relation to the direct and concrete military advantage anticipated. ${ }^{22}$

The questions which remain the subject of discussion once one decides to apply

19 Henckaerts \& Doswald-Beck, supra note 10, Rule 14, Vol. I -Rules at 46-50, Vol. II - Practice at 297-335.

20 There is, however, a developing literature which explores the general concept of proportionality and sheds some light on practical applications. This includes: Judith Gardam, Necessity, Proportionality and the Use of Force by States (Cambridge: Cambridge University Press, 2004); Kenneth Watkin, "Assessing Proportionality: Moral Complexity and Legal Rules" (2005) 8 Y. B. Int'l Human. L. 3; Noam Neuman, "Applying the Rule of Proportionality: Force Protection and Cumulative Assessment in International Law and Morality”, (2004) 7 Y. B. Int'l Human. L 79; and Thomas M. Franck, "On Proportionality of Countermeasures in International Law" (2008) 102 A.J.I.L. 715.

21 Prosecutor $v$ Galic, ICTY Case No. IT-98-29-T. Judgment and Opinion. 5 December 2003.

22 Ibid. at para 387. 
the principle of proportionality include the following:

a) Who should make the decisions on application of the principle in a particular case?

b) What is to be compared and what is the standard for comparison?

c) What are the relative values to be assigned to the military advantage gained and the injury to non-combatants and or the damage to civilian objects?

d) What do you include or exclude in totaling your sums?

e) What is the scale of measurement in time or space?

f) To what extent is a military commander obligated to expose his own forces to danger in order to limit civilian casualties or damage to civilian objects? ${ }^{23}$

The answers to these questions are not simple; each may need to be resolved on a case by case basis, and the answers may differ depending on the background and values of the decision maker; a human rights lawyer and an experienced combat commander would probably not assign the same relative values to military advantage and to injury to noncombatants. Further, it is unlikely that military commanders with different doctrinal backgrounds and differing degrees of combat experience or national military histories would always agree in close cases. At first instance, the determination of relative values will often be that of the "reasonable military commander," as he or she will be the one who must make an attack decision although, on occasion, such decisions will be reserved for higher level authorities, including those at the political level. ${ }^{24}$ Although there will be room for argument in close cases, there will be many cases where reasonable military commanders will agree that the injury to noncombatants or the damage to civilian objects was clearly disproportionate to the military advantage gained. The Galic Trial Chamber held that the decision maker should be regarded as "a reasonably well-informed person in the circumstances of the actual perpetrator, making reasonable use of the information available to him or her." ${ }^{25}$ Implicitly, this would appear to endorse the decision maker as the "reasonable" political or military leader.

23 Anthony P.V. Rogers, “Zero-casualty Warfare” (2000) 837 Int'l Rev. Red Cross 165-81 suggests that no risk warfare is unheard of and, if a target is sufficiently important, higher commanders may be willing to accept a higher degree of risk to ensure that the target is properly identified and accurately attacked.

24 For US practice during the Kosovo Campaign, see James E. Baker, "Judging Kosovo: The Legal Process, The Law of Armed Conflict, and the Commander In Chief” in Andru E. Wall, ed., Legal and Ethical Lessons of NATO's Kosovo Campaign (Newport: Naval War College, 2002) at 6-18.

25 Galic, supra note 21, para 58. 
The proportionality process compares the anticipated concrete and direct military advantage with the anticipated incidental loss of civilian life, injury to civilians, damage to civilian objects or a combination thereof. The actual results may assist in inferring the intent of the attacker as he or she launched the attack but what counts is what was in the mind of the decision maker when the attack was launched. The attack is prohibited if it is anticipated it will result in excessive civilian losses in comparison with the anticipated concrete and direct military advantage. The Galic Trial Chamber addressed the scope of "concrete and direct military advantage" as follows:

The travaux preparatoires of Additional Protocol I indicate
that the expression "concrete and direct" was intended to
show that the advantage must be "substantial and relatively
close" and that "advantages which are hardly perceptible and
those which would only appear in the long term should be
disregarded." ICRC Commentary, para. 2209. The Com-
mentary explains that "a military advantage can only con-
sist in ground gained or in annihilating or in weakening the
enemy armed forces." ICRC Commentary, para. $2218 .^{26}$

The approach taken in Galic and by the ICRC concerning "concrete and direct military advantage" may be unduly restrictive. The military advantage gained by a successful attack on a military objective may vary somewhat depending on circumstances. For example, a successful attack on a military objective such as an artillery emplacement always gives the attacker a military advantage but the extent of the concrete and direct military advantage may vary depending on factors such as the location of the objective or its current or potential use.

What are the relative values to be assigned to the military advantage gained and the injury to civilians or the damage to civilian objects? There is no agreed standard and, further, the comparison is between unlike quantities. As an educated guess, if all that is being quantified is death or injury to people, it is unlikely that the death or injury of a soldier would be regarded as less valuable than that of a civilian. A value must also be assigned to material military objectives aimed at, destroyed or damaged. Existing literature provides no assistance on this vital point. Although there has been some discussion concerning what is to be included in the equation, there are still some unresolved issues. How does one regard civilian workers on a military base or so-called voluntary hostages such as civilians who deliberately attempt to shield a military objective? In my view, the answer is that both munitions workers and voluntary hostages are civilians and are included in the civilians' side of the equation but not all would agree.

Determining the proper standard of measurement in time or space (geographic extent) for applying the proportionality equation is also difficult. The standard of measurement must be one that it is practicable to use in advance, and also use later to determine whether the proportionality requirement is being met at various stages in the conflict. One cannot, for example, assert that it will only

26 Ibid. at para. 58 , note 6 . 
be possible to determine whether or not military activity complied with the proportionality principle at the end of the war or when a lengthy campaign is over; at the same time, one cannot always assess proportionality on a bullet-by-bullet basis or even, always, on the basis of attacks on individual military objectives. Several states made statements of interpretation concerning the application of "military advantage" considered in the context of Articles 51, 52, and 57 when ratifying or acceding to $A P I$. The statement by Canada is representative:

It is the understanding of the Government of Canada in relation to Articles 51(5)(b), 52(2), and 57(2)(a)(iii) that the military advantage anticipated from an attack is intended to refer to the advantage anticipated from the attack considered as a whole and not from isolated or particular parts of the attack. $^{27}$

Such statements notwithstanding, it is suggested that proportionality can be determined using a variety of scales ranging from the tactical level (military objective by military objective) to a much bigger scale as long as the more general context is also taken into account. ${ }^{28}$ For example, if it is essential to block military traffic across a river and the enemy forces may use one of three bridges to cross the river, it may well be permissible to inflict greater collateral losses for destroying the last bridge because of the resultant greater military advantage. The military objective scale is commonly used in modern state practice, particularly in assessing the legitimacy of aerial attacks.

\section{WHAT IS TO BE DONE}

There are advantages to be derived from a lack of clarity concerning what things are military objectives and whether or not an attack is anticipated to cause disproportionate losses. Lawyers advising operational decision makers may be better able to protect their clients. Lawyers engaged in advocacy on behalf of NGOs may be able to stretch the legal envelope in a progressive direction. It is the premise of this article, however, that a greater degree of agreement and clarity concerning these concepts will contribute to the fundamental purpose of IHL, reducing civilian losses and net human suffering. One way in which these concepts can be clarified further is by the development of a dialogue involving informed and interested parties similar to the Harvard Project on the Means of Intervention or the ICRC project which resulted in guidance concerning Direct Participation in Hostilities. ${ }^{29}$ Such a dialogue might resolve the concepts into various components and also use well articulated case studies of real or hypothetical events in order to examine how the concepts can be applied in

27 Schindler \& Toman, supra note 7 at 798.

28 In a 1982 article, supra note17 at 112, the author expressed the view that the AP I proportionality provisions would probably not be applicable below a divisional level attack. He now disagrees with his younger self.

29 Supra notes 3 and 6. 
practical situations. A discussion detached from concrete examples might help clarify whether or not civilian morale could or should be regarded as a military objective. Concrete examples would be essential, however, to clarify the values to be assigned on both sides of the proportionality equation. ${ }^{30}$

Persons taking part in the dialogue should be adequately informed of military realities and of the relevant parts of IHL. This does not mean they must have a military background. It is possible to develop and provide information packages and discussion sessions which can provide the basic information although such will not, of course, provide the intuitive feel for military issues which one can expect from a trained military professional. ${ }^{31}$ For example, participants must be aware of the fact that projectiles do not necessarily land where they are aimed. Generally speaking, munitions from anything other than small arms can, at best, be expected to land within a particular area around the point at which they are aimed. The area is given different names in different armed forces, such as Circular Error Probable [CEP] or Error Ellipse. These expressions are used to indicate the percentage of munitions fired from a particular weapons system which can be expected to land within a given area from the aiming point. They must also be aware of the ranges and the effects of weapons. Further, particularly if they are intending to impute liability, they must be aware of how armed forces function, their structure, command and control systems, reporting mechanisms, and doctrine. ${ }^{32}$ Just as the non-military participants in the dialogue should be informed of the relevant military factors, so should military participants who are not IHL specialists be adequately informed of the relevant parts of IHL. Ideally, the dialogue and the discussion of well prepared case studies should involve military personnel with operational experience, military lawyers with experience advising on IHL during operations, military IHL experts (not always the same as the last group), and lawyers and others from the academic and NGO IHL community. The non-military participants should include persons from NGOs who have been involved in bomb damage analysis and collateral damage analysis on behalf of NGOs.

30 If practical application is at issue, the scope of military objective and the relative value of military advantage and civilian losses must be considered together. Joseph Holland, "Military Objective and Collateral Damage: Their Relationship and Dynamics," (2004) 7 Y. B. Int'l Human. L 35.

31 The Harvard Means of Intervention Project, supra note 3, was intended to provide a common basis of understanding at a relatively abstract level. Michael N. Schmitt \& R.A. Coe, "Fighter Ops for Shoe Clerks" (1997) 42 A.F.L. Rev. 49 was written to provide legal advisers in the United States Air Force with an overview of the operational knowledge deemed essential to provide advice on IHL matters. Similar articles, keyed to particular armed forces and available technology, would be helpful in providing this common basis. For example, an article along these lines addressing air and ground operations, on all sides, in Afghanistan would be invaluable in situating lawyers to discuss IHL issues related to Canadian participation in that conflict.

32 In cases before the ICTY, a tribunal where judges and lawyers were not expected to have a military background, military analysts, ballistics experts, command and control experts, and military operational personnel were involved in case preparation and testified as experts. Fenrick, supra note 4 , at 159-64. 
It is to be hoped that the armed forces of countries such as Canada which take their IHL responsibilities seriously have already undertaken such studies on a national or multinational basis. It is suggested, however, that conducting such studies in an unclassified environment will contribute to clarifying the law and to ensuring that IHL continues to develop as a body of law rooted in common understandings. 